\title{
Peningkatan Kapasitas Organisasi Kepemudaan Kabupaten Banyumas Dalam Menghadapi ASEAN Community 2015
}

\begin{abstract}
Elpeni Fitrah ${ }^{1}$
Abstrak

Penelitian ini bertujuan untuk mencari formula yang tepat untuk memperkuat kapasitas organisasi kepemudaan di Kabupaten Banyumas dalam menghadapi ASEAN Community 2015. Organisasi kepemudaan yang dilibatkan dalam kegiatan ini diharapkan nantinya dapat berperan dan berkontribusi bagi komunitasnya untuk mempersiapkan diri dalam menghadapi diberlakukannya ASEAN Community 2015. Penelitian ini menggunakan metode kualititatif dengan pendekatan action research. Peneliti membangun kesimpulan berdasarkan pengamatan dan observasi pada organisasi kepemudaan dibawah koordinasi Komite Nasional Pemuda Indonesia Kabupaten Banyumas. Pemilihan KNPI Kabupaten Banyumas sebagai mitra kegiatan karena organisasi ini adalah induk dari banyak organisasi kepemudaan dengan berbagai macam platform. Organisasi-organisasi kepemudaan adalah instrumen potensial sebagai agen sosialisasi ASEAN Community sekaligus yang paling mampu untuk mem-breakdown rencana aksi pemberdayaan masyarakat agar siap menghadapi ASEAN Community 2015
\end{abstract}

Kata-kata Kunci: AC 2015, Organisasi Kepemudaan, KNPI, ASEAN, Regionalisme

\begin{abstract}
Abstrak
This research aims to find the right formula to strengthen the capacity of youth organization in the Banyumas district to face ASEAN community. Youth organization who were involved in this activity is hoped can participate and contribute to their communities to prepare themselves in the face of 2015 ASEAN Community. This research using qualitative methods by action research approach. Researchers build conclusions based on observations on youth organization under coordination of (KNPI) Indonesian Youth National Committee of Banyumas district. The selection of KNPI as a partner because the activities of this organization is the umbrella of numerous youth organizations with different kinds of a platform in Banyumas. The youth organizations is a potential tool as an agent of the socialization of ASEAN Community to breakdown a plan of action of community empowerment to be ready for 2015 ASEAN Community.
\end{abstract}

Keywords: AC 2015, Youth Community, KNPI, ASEAN, Regionalism

\section{Pendahuluan}

Pembentukan Komunitas ASEAN 2015 menunjukkan upaya negara-negara di kawasan Asia Tenggara untuk terintegrasi secara masif dalam berbagai bidang untuk menyongsong era globalisasi. Melalui integrasi regional ini diharapkan ASEAN akan semakin stabil dalam bidang keamanan, kuat dalam mempertahankan budaya dan sejahtera dalam tataran ekonomi kawasan. Pembentukan komunitas ASEAN juga dilatarbelakangi kebutuhan institusi regional ASEAN untuk mentransformasikan dirinya dan merangkul semua stakeholders serta masyarakat ASEAN untuk berkontribusi dan berperan di kawasan sebagai subjek-subjek aktif di era globalisasi. Ada 3 pilar ASEAN Community ini yaitu pilar Politik dan Keamanan (ASEAN PoliticalSecurity Community), pilar Sosial-Budaya (ASEAN Social-Political Community), dan pilar Ekonomi (ASEAN Economic Community).

Dalam skema komunitas ASEAN, peran pemuda (youth) menjadi sentral untuk mencapai tujuan-tujuan tersebut diatas. Kata

\footnotetext{
${ }^{1}$ Staf pengajar di Jurusan Hubungan Internasional, Universitas Jenderal Soedirman. Email: elpeni.fitrah@yahoo.com
} 
kunci komunitas ASEAN disini ialah penghargaan kepada civil society atau masyarakat untuk berperan besar dalam menggerakkan potensi diri maupun potensi daerahnya. Kita ketahui bahwa strategi pembangunan yang (hanya) memusatkan perhatian kepada akumulasi modal dan pertumbuhan ekonomi sebagai pendorong kesejahteraan telah banyak dikritik (Arndt, 1989; 49-87). Strategi pembangunan yang baik adalah menyertakan upaya peningkatan kualitas dan kapasitas sumber daya manusia untuk menciptakan pertumbuhan dan kesejahteraan (Effendi, 1995; 31). Pemuda sebagai kelompok usia produktif, potensial menjadi modal utama pembangunan. Bukan semata menjadi obyek, yang dianut oleh paradigma pembangunan lama, namun sebagai subyek, agen, promotor, akselerator dan partisipator yang mampu merubah dan memperbaiki kualitas diri, kualitas masyarakat, hingga kualitas pembangunan nasional dan regional.

Kabupaten Banyumas adalah kabupaten yang letaknya strategis dan potensial dalam pembangunan daerah. Tingkat pertumbuhan penduduk usia produktif di Kabupaten Banyumas juga mengalami peningkatan setiap tahunnya. Data tahun 2006 di bidang ketenagakerjaan menyebutkan bahwa penduduk Kabupaten Banyumas usia muda cukup tinggi yaitu sekitar 26,28 \% sedangkan penduduk usia lanjut (65 tahun keatas) sebesar 7,17\% sehingga rasio beban ketergantungan dimana setiap dua orang usia produktif menanggung sekitar satu orang yang dianggap belum atau tidak produktif. Dalam bidang kepemudaan, organisasi-organisasi pemuda di Banyumas sebagai wadah pengembangan potensi pemuda cukup beragam, antara lain: organisasi berorientasi nasionalis yaitu Karang Taruna, KNPI (Komite Nasional Pemuda Indonesia) dan PP (Pemuda Pancasila), organisasi berorientasi keagamaan seperti IPNU (Ikatan Pemuda NU) dan Pemuda Muhammadiyah, maupun organisasiorganisasi mahasiswa seperti BEM, HMI, GMNI, FMN dll. Potensi Kabupaten Banyumas sebagai kota pendidikan dapat dilihat melalui semakin banyak dan berkembangnya pendidikan tinggi di Kabupaten ini dengan kuantitas berkisar antara 20 universitas/perguruan tinggi.

ASEAN Community 2015 tidak hanya mendatangkan peluang namun juga tantangan bagi masyarakat. Terutama dalam cetak biru Komunitas Ekonomi ASEAN yang menyebutkan bahwa tujuan dari MEA adalah liberalisasi perdagangan di tingkatan ASEAN untuk menyongsong globalisasi. Liberalisasi perdagangan ini mensyaratkan adanya arus bebas perpindahan barang dan jasa, manusia, modal hingga tenaga kerja dari dan ke negaranegara di ASEAN dari tingkat nasional hingga penetrasi di tingkatan lokal Banyumas. Belum lagi skema Perdagangan Bebas dengan China yang sudah berlaku, berkonsekuensi kepada semakin kompetitifnya pasar barang maupun 
pasar tenaga kerja. Apabila SDM masyarakat rendah dan daya saing produk di masyarakat lemah, bisa jadi masyarakat akan dirugikan dengan skema pasar bebas ASEAN ini.

Menghadapi ASEAN Community 2015 ini, terutama Masyarakat Ekonomi ASEAN, organisasi pemuda di Kabupaten Banyumas perlu mengambil peran signifikan untuk melakukan serangkaian upaya memperkuat basis sumber daya manusia di tingkatan daerah. Hal ini dapat dilakukan dengan melakukan peningkatan kapasitas organisasi pemuda untuk pada awalnya membangun kesadaran kolektif tentang pentingnya peran pemuda dalam ASEAN Community dan selanjutnya menyebarluaskan atau sosialisasi pengetahuan tentang ASEAN Community kepada masyarakat luas. Dalam hal ini, pemuda perlu dikembalikan kepada hakikat dan posisinya di masyarakat untuk menjadi penggerak utama, agen sosial, dan subyek yang menentukan dalam perumusan strategi pembangunan daerah, bersinergi baik di level masyarakat hingga level pembuat kebijakan.

Peneliti berharap riset ini dapat menghasilkan beragam manfaat bagi peningkatan kapasistas organisasi kepemudaan di Kabupaten Banyumas dalam menghadapi ASEAN Community 2015. Beberapa diantaranya adalah tersampaikannya wacana mengenai implementasi ASEAN Community 2015 di kalangan organisasi kepemudaan, Munculnya kesadaran dan semangat positif organisasi kepemudaan untuk mempersiapkan diri dalam menghadapi ASEAN Community 2015, munculnya gagasan baru dari organisasi kepemudaan untuk berperan aktif dalam sosialiasi ASEAN Community 2015 yang mengarah pada pemberdayaan masyarakat, dan tersusunnya program-program dan aktivitas yang berhubungan dengan peningkatan kapasitas organisasi kepemudaan dalam menghadapi ASEAN Community 2015.

\section{Permasalahan}

Permasalahan utama yang dihadapi organisasi kepemudaan di Kabupaten Banyumas dalam konteks implementasi kesepakatan regional adalah belum adanya program-program yang menyentuh kebutuhan masyarakat terutama program peningkatan pengetahuan dan partisipasi masyarakat mengenai ASEAN Community. Organisasi kepemudaan terlalu disibukkan di ranah politik praktis sehingga belum optimal untuk menjadi agen perubahan sosial di masyarakat. Sebagai contoh organisasi Karang Taruna di Kabupaten Banyumas ada sekitar 331, namun sekitar 53 diantaranya dinyatakan mati suri. Hal ini karena lemahnya penguatan kapasitas kelembagaan, kesulitan dalam regenerasi kepengurusan serta lemahnya inisiatif pemuda itu sendiri untuk berkesadaran atau berperan dalam pembangunan desa, apatah lagi mempunyai pengetahuan memadai tentang fenomena nasional atau regional seperti ASEAN Community 2015.

Beberapa permasalahan yang dihadapi 
oleh khalayak sasaran Penguatan Kapasitas Organisasi Kepemudaan dalam Menghadapi ASEAN Community adalah sebagai berikut: 1) Belum adanya pengetahuan dan pemahaman yang kuat di kalangan organisasi kepemudaan Kabupaten Banyumas mengenai ASEAN Community 2015, 2) Belum terbentuknya kesadaran kolektif organisasi kepemudaan untuk mempersiapkan diri menghadapi diberlakukannya ASEAN Community 2015, 3) Belum adanya program dan kegiatan yang kongkrit dari organisasi kepemudaan mengenai ASEAN Community 2015, 4) Belum adanya mitra kerja baik dari pemerintah daerah bidang kepemudaan maupun akademisi dalam mensosialisasikan implementasi ASEAN Community 2015.

\section{Metode}

Penelitian ini menggunakan metode kualititatif dengan pendekatan action research. Penggunaan metode dan pendekatan ini dengan tujuan agar memperoleh bahan empiris dari hasil pengamatan langsung dan wawancara untuk menggambarkan momenmomen problematik dan kehidupan sehari-hari serta makna yang ada di dalam kehidupan individu (Denzin dan Lincoln dalam Creswell, 1998:15). Penulis melakukan pengamatan dan observasi bersama organisasi kepemudaan sejumlah organisasi kepemudaan di Kabupaten Banyumas dibawah koordinasi Komite Nasional Pemuda Indonesia Kabupaten Banyumas.
Beberapa metode yang akan diterapkan yakni: A. Analisis situasi untuk mendapat gambaran mengenai iklim sosial di wilayah objek penelitian
B. Analisis permasalahan
C. Pelatihan dan Sosialisasi. Pada sesi ini peserta akan diberi pembekalan mengenai peran organisasi kepemudaan dalam menghadapi ASEAN Community 2015. Para pemateri berasal dari Jurusan Hubungan Internasional UNSOED, Dinas Pemuda,Olahraga, budaya, dan pariwisata Kabupaten Banyumas, dan perwakilan dari KNPI

D. Penyusunan kerangka kerja mengenai peran strategis organisasi kepemudaan Kabupaten Banyumas dalam rangka menghadapi ASEAN Community 2015.

E. Evaluasi. Hal ini dilakukan dalam dua bentuk. Pertama, oleh internal tim pengabdian masyarakat bersama mitra kerjasama untuk melihat apakah pembekalan materi sudah sesuai dengan tujuan awal program pengabdian masyarakat. Kedua, mengevaluasi keterserapan materi oleh para peserta program. Indikator untuk mengukur hal ini adalah dengan melihat apakah pasca mengikuti pelatihan, peserta program mengalami peningkatan pengetahuan dan kesadaran mengenai peran penting organisasi kepemudaan dalam menghadapi ASEAN Community 2015. 


\section{Kerangka Konsep}

\section{Tentang Konsepsi Pemuda}

Menurut UU No. 40 Tahun 2009, pemuda ialah warga negara Indonesia yang memasuki periode penting pertumbuhan dan perkembangan yang berusia 16 (enam belas) sampai 30 (tiga puluh) tahun. Pandangan yang lebih luas mengenai pemuda dapat mdilihat dari kajian Bourdieu and Wacquant (1992) yang menyebutkan bahwa pemuda (youth) ialah hasil dari konstruksi sosial yang berkaitan dengan konteks, sejarah dan juga relasi kuasa dalam kurun waktu tertentu. Pemuda dikonstruksikan dan sekaligus mampu mengkonstruksikan dirinya sebagai sebuah entitas yang mempunyai dua sisi berlawanan, yaitu sebagai pahlawan (heroes) ataupun penjahat (villains) (Jones; 2009), atau dengan kata lain terdapat potensi positif (tonic) maupun racun (toxic) sebagaimana dijelaskan oleh Nasikun (2005).

Secara holistis, cara memandang terhadap pemuda berkaitan dengan standing position dari pihak yang berkepentingan (negara, pasar, masyarakat) dan selanjutnya akan berdampak pada perspektif dan aksi yang dilakukan kepada pemuda itu sendiri. Apabila pemuda diberi peran yang besar misalnya oleh negara untuk dilakukan internalisasi nilai-nilai nasionalisme dan kebangsaan, maka pemuda menjadi subjek yang berperan besar dalam stabilitas sistem sosial suatu rezim di sebuah negara. Di sisi lain, mekanisme pasar juga bisa mengkonstruksi pemuda sebagai konsumen aktif sekaligus komoditas yang menjadi ikon pasar untuk memaksimalkan keuntungan. Sedangkan dari sisi masyarakat, pemuda bisa menjadi agen perubahan dan subjek bebas yang berada di garda depan yang menentukan tatanan sosial. Melalui beberapa pandangan diatas dapat disimpulkan mengenai pendefinisian pemuda ialah apakah pemuda hanya merupakan golongan usia tertentu, ataukah sebagai kelas sosial dalam masyarakat dimana mempunyai dua potensi, bisa merusak dan bisa juga membangun. Sebagai pihak yang bergantung pada pasar atau kekuasaan, ataukah sebagai subjek otonom atau mandiri yang mempunyai kekuatan sendiri untuk merubah tatanan sosial.

\section{Penguatan Kapasitas (Capacity Building)}

$$
\text { Penguatan kapasitas atau }
$$

pengembangan kapasitas adalah konsep yang lebih luas dibanding konsep mengenai perkembangan organisasi yang dimana mencakup mekanisme sistem secara keseluruhan, lingkungan sekaligus konteks di dalamnya dimana individu, organisasiorganisasi dan masyarakat saling berhubungan dan berinteraksi (UNDP 1998). Menurut World Bank (1998) menyebutkan bahwa kapasitas adalah kombinasi dari keseluruhan manusia, institusi dan praktek-praktek yang dilakukan yang memberikan mandat kepada negara-negara untuk mencapai tujuan-tujuan pembangunan. Pembangunan kapasitas adalah 
investasi dalam human capital, institusi dan perilaku atau tindakan-tindakan. Sedangkan AusAID 2004 menyebutkan definisi konseptual mengenai pembangunan kapasitas ialah serangkaian proses dari pembangunan kompetensi dan kapabilitas individu, kelompok, organisasi dan sektor atau negara yang akan membawa ke arah keberlanjutan untuk meraih peningkatan prestasi.

Dewasa ini upaya pengembangan kapasitas merupakan bagian yang penting di dalam berbagai aspek kehidupan. Hal ini tidak luput dilakukan juga oleh organisasi publik. Dalam kehidupan sehari-hari pengembangan kapasitas misalnya dilaksanakan dengan pendidikan, baik secara formal maupun informal. Di dalam perusahaan misalnya melalui pelatihan-pelatihan sumberdaya manusia, pengembangan sistem manajerial. Di dalam pemerintahan pengembangan kapasitas aparatur pemerintahan juga penting untuk meningkatkan performa aparatur dalam menjadalankan tugasnya sebagai abdi negara, dan juga regulasi dan deregulasi kebijakan pemerintahan. Dalam konteks pembangunan secara keseluruhan pun upaya pengembangan kapasitas menjadi bagian yang tidak terpisahkan. Dengan kata lain tidak mungkin terjadi suatu proses pembangunan atau pengembangan dalam hal apapapun tanpa upaya pengembangan kapasitas bagi pelaku, organisasi, maupun juga sistem yang mengaturnya.

Konsep mengenai Pembangunan
Kapasitas (Capacity Building) ini akan dijadikan sebagai acuan untuk merancang model penguatan kapasitas organisasi kepemudaan di Kabupaten Banyumas dalam rangka mempersiapkan diri untuk menghadapi ASEAN Community 2015.

\section{ASEAN Community}

Tujuan pembentukan Komunitas Regional ini adalah salah satu diantaranya, bagaimana sebuah organisasi regional mampu mempertahankan diri atau menguatkan diri di tengah semakin kompetitifnya persaingan global. Sebagai contoh, dalam cetak biru Komunitas Sosio-Kultural ASEAN dijelaskan bahwa Komunitas ini dibentuk salah satunya adalah untuk melindungi efek negatif dari globalisasi dengan mempertahankan dan mempromosikan budaya, nilai dan norma yang membentuk komunitas ASEAN (ASEAN, 2009). Kebutuhan-kebutuhan tentang kebebasan berinvestasi, pembangunan infrastruktur, arus barang dan jasa serta tenaga kerja terampil diharapkan mendongkrak perekonomian ASEAN dan mampu ditangkap peluangnya secara maksimal oleh negaranegara di ASEAN (ASEAN, 2008). Sedangkan dalam cetak biru komunitas politik dan keamanan, konsekuensi dari era globalisasi yaitu suatu proses kesalinghubungan dan kesalingbergantungan membuat negara-negara di ASEAN juga harus menyiapkan diri untuk mengatur kebebasan perpindahan manusia, barang dan jasa, ide-ide seperti HAM dan 
identitas ASEAN yaitu budaya, nilai dan norma yang membentuk komunitas ASEAN (ASEAN, 2009). Kebutuhan-kebutuhan tentang kebebasan berinvestasi, pembangunan infrastruktur, arus barang dan jasa serta tenaga kerja terampil diharapkan mendongkrak perekonomian ASEAN dan mampu ditangkap peluangnya secara maksimal oleh negaranegara di ASEAN (ASEAN, 2008). Sedangkan dalam cetak biru komunitas politik dan keamanan, konsekuensi dari era globalisasi yaitu suatu proses kesalinghubungan dan kesalingbergantungan membuat negara-negara di ASEAN juga harus menyiapkan diri untuk mengatur kebebasan perpindahan manusia, barang dan jasa, ide-ide seperti HAM dan demokrasi, arus teknologi dan informasi maupun isu-isu tertentu termasuk isu yang mengancam seperti kejahatan transnasional yang harus ditindaklanjuti (ASEAN, 2009).

\section{Pembahasan}

Organisasi kepemudaan seharusnya memegang peran sentral dalam menghadapi ASEAN Community 2015. Pendapat itu menjadi relevan karena pada 2020 diproyeksikan jumlah penduduk usia produktif masih lebih banyak daripada penduduk usia non-produktif, yang disebut dengan bonus demografi. Konsepsi ideal itu sejauh ini belum tampak di Kabupaten Banyumas. Berdasarkan wawancara singkat dengan salah satu organisasi kepemudaan di Kabupaten Banyumas membenarkan bahwa program dan kegiatan-kegiatan yang berhubungan dengan wacana integrasi tunggal ASEAN yang sebentar lagi akan diberlakukan masih sangat minim dilaksanakan. Itu disebabkan karena organisasi kepemudaan di Kabupaten Banyumas masih sering terseret pada pusaran arus politik praktis sehingga lupa ada sesuatu yang sangat besar sebentar lagi akan menghampiri kita yakni ASEAN Community 2015.

Oleh sebab itu maka program pertama yang perlu dilakukan untuk mengatasi masalah apatis organisasi kepemudaan terhadap wacana ASEAN Community adalah mengembalikan kesadaran dan mindset bahwa organisasi kepemudaan tidak boleh melulu hanya bergerak di ranah politik praktis, melainkan memahami bahwa organisasi kepemudaan seharusnya mengambil peran yang jauh lebih besar sebagai penopang ketahanan nasional dari segala ancaman. Untuk mendukung misi tersebut maka perlu disusun langkah-langkah nyata penguatan kapasitas organisasi kepemudaan dalam menghadapi ASEAN Community 2015, seperti:

1. Meyediakan forum-forum diskusi untuk memperkaya pemahaman organisasi kepemudaan mengenai ASEAN Community 2015

2. Mendata organisasi kepemudaan di Kabupaten Banyumas yang potensial sebagai agen sosialisasi ASEAN Community kepada masyarakat luas

3. Bekerjasama sama dengan pemerintah 
daerah, dalam hal ini Dinas Pemuda, Olahraga, Budaya dan Pariwisata (Disporabudpar) Kabupaten Banyumas untuk menyelenggarakan kegiatan pelatihan penguatan kapasitas organisasi kepemudaan dalam menghadapi ASEAN Community 2015

Pihak kampus melakukan pendampingan kepada organisasi kepemudaan dalam menyusun dan melaksanakan programprogram yang berhubungan dengan persiapan menghadapi diberlakukannya ASEAN Community 2015.

Arif Darmawan, M.Si, Dosen Jurusan Hubungan Internasional Universitas Jenderal Soedirman menjelaskan tentang konsepsi kepemudaan dan perannya dalam menghadapi ASEAN Community 2015. Arif mengatakan Pemuda adalah bagian dari masyarakat secara umum dan relatif memiliki usia muda sehingga diharapkan lebih memiliki potensi, etos kerja dan kreatifitas yang lebih jika dibandingkan dengan masyarakat yang sudah menginjak usia tua. Dalam perspektif Undang-undang No.40 tahun 2009 tentang kepemudaan, pasal 1 berbunyi: yang dimaksudkan pemuda adalah warga negara Indonesia yang memasuki periode penting pertumbuhan dan perkembangan yang berusia 16 sampai 30 tahun. Labih lanjut dalam peraturan perundangan yang dimaksud di atas dijelaskan pula peran, tanggung jawab, dan hak pemuda dalam pasal 16 berbunyi: pemuda berperan aktif sebagai kekuatan moral, kontrol sosial, dan agen perubahan dalam segala aspek pembangunan nasional. Kemudian pemerintah memiliki tanggung jawab memfasilitasi dan membimbing para pemuda (sebagai hak pemuda) untuk mengembangkan dirinya agar siap menjadi penerus tongkat estafet kepemimpinan bangsa dan negara melalui upaya pemerintah seperti: Penyadaran, Pemberdayaan, dan Pengembangan yang kesemuanya tertuang secara rinci dalam UU No.40/2009 tentang Kepemudaan tertutama pengembangan di bidang kepemimpinan dan kewirausahaan yang sangat relevan dalam pembahasan peran serta pemuda dalam menyongsong Masyarakat Ekonomi ASEAN 2015.

Peran pemerintah dalam mengembangkan sektor kepemudaan ini adalah langkah yang sangat strategis dan berimplikasi jangka panjang dalam menjawab tantangan dan rintangan serta kendala MEA 2015. Hal ini berguna untuk menciptakan sumber daya manusia yang bukan saja berkualitas secara akdemis namun juga dapat menjawab kebutuhan pasar tenaga kerja ASEAN dan bahkan dunia, mengingat sering dikeluhkan bahwa kualitas lulusan pendidikan tinggi kita tidak berbanding lurus dengan kebutuhan pasar tenaga kerja, akhirnya lulusan sarjana sering harus menelan pil pahit karena harus menjadi pengangguran intelektual setelah lulus kuliah karena tidak memiliki daya saing dan kualifikasi pasar tenaga kerja.

Tantangan akan semakin terbuka jika melihat kebijakan beberapa negara ASEAN 
seperti Filipina dan Thailand misalkan, kedua negara tersebut sudah lama membekali kesiapan anak mudanya dalam menghadapi MEA 2015 dengan membekali mereka selain keahlian teknis dalam berwirausaha, mereka juga diberikan pelajaran berbahasa Indonesia dan Inggris dalam memudahkan aktivitas transaski sosial ekonomi dalam pasar ASEAN khususnya Indonesia. Hal ini karena Indonesia adalah sasaran utama bagi pelaku ekonomi, disebabkan Indonesia merupakan hampir separuh dari pasar ASEAN dengan rentang jumlah penduduk yang besar tersebut yang telah disinggung berulang kali diatas.

Ini akan berimplikasi negatif dalam hal ini merugikan kepentingan nasional, disisi lain pula jika dikelola dengan baik dan dengan program aksi yang berkelanjutan bukan tidak mungkin justru menjadi kesempatan emas bangsa kita dan para anak muda mengembangkan dan memasarkan karir dan produknya kepasar yang lebih luas pula. Artinya dalam MEA 2015 Indonesia harusnya bukan semata menjadi sasaran pasar yang sangat potensial itu namun juga berpotensi menjadi subjek dan atau pelaku ekonomi aktif dalam perannya pada mendorong terwujudnya komunitas ASEAN.

Jika melihat tagline baru Kabupaten Banyumas yang berbunyi "Better Banyumas", maka didalamnya terpampang mindset bahwa Kabupaten Banyumas telah memiliki strategi pembangunan yang tidak hanya inward looking tapi juga outward looking. Yang dimaksud perpindahan dari inward looking ke outward looking adalah sebagai berikut: upaya mendorong terciptanya perdagangan bebas. Karena itu strategi promosi ekspor dilakukan untuk menciptakan pasar ekspor melalui efisiensi. Hal inilah yang perlu dilakukan oleh Kabupaten Banyumas agar siap menghadapi persaingan Masyarakat Ekonomi ASEAN yang akan datang.

\section{Kesimpulan dan Saran}

Penelitian ini diharapkan dapat meningkatkan peran dan kapasitas organisasi kepemudaan dalam menghadapi integrasi regional yang bernama ASEAN Community 2015. Hal ini untuk mencapai Kata kunci komunitas ASEAN berupa penghargaan kepada civil society atau masyarakat untuk berperan besar dalam menggerakkan potensi diri maupun potensi daerahnya. Kita ketahui bahwa strategi pembangunan yang (hanya) memusatkan perhatian kepada akumulasi modal dan pertumbuhan ekonomi sebagai pendorong kesejahteraan telah banyak dikritik. Strategi pembangunan yang baik adalah menyertakan upaya peningkatan kualitas dan kapasitas sumber daya manusia untuk menciptakan pertumbuhan dan kesejahteraan. Pemuda sebagai kelompok usia produktif, potensial menjadi modal utama pembangunan. Bukan semata menjadi obyek, yang dianut oleh paradigma pembangunan lama, namun sebagai subyek, agen, promotor, akselerator dan 
Elpeni Fitrah

partisipator yang mampu merubah dan

memperbaiki kualitas diri, kualitas

masyarakat, hingga kualitas pembangunan

nasional dan regional.

\section{Daftar Pustaka}

ASEAN Socio-Cultural Community Blueprint. 2009. Jakarta: ASEAN Secretariat.

ASEAN Political Security Community Blueprint. 2008. Jakarta: ASEAN Secretariat

ASEAN Economic Community Blueprint. 2008. Jakarta: ASEAN Secretariat.

Association Southeast Asian Nations. 2009. Roadmap for an ASEAN Community 2009-2015. Ja-

karta: ASEAN Secretariat

Arndt, H. W. 1989. Economic Development: The History of An Idea, Chicago, The

University of Chicago Press.

Berger, Peter 1 and Hansfried Kellner. 1981. Sociology Reintepreted. Basic Book : USA.

Bourdieu, Pierre and Loic Wacquant.1992. Invitation to Reflexive Sociology. Cambridge:

Polity Pres.

Jennings, Louise B. et al. "Toward a Critical Social Theory of Youth Empowerment." dalam

Journal of Community Practice (The Haworth Press, Inc.) Vol. 14, No. 1/2, 2006,

hlm. 31-55; dan: Youth Participation and Community Change (ed: Barry N. Checkoway, \&

Lorraine M. Gutiérrez), The Haworth Press, Inc., 2006, hlm. 31-55.

Jones, Gill. 2009. Youth. England : Polity Press.

Nasikun.2005. Peran Ilmu-Ilmu Sosial dan Humaniora bagi Liberasi dan Humanisasi

Teknologi. Sekolah Pascasarjana Universitas Gadjah Mada : Yogyakarta. 